\title{
EFEKTIVITAS TEKNIK MODELING UNTUK MENINGKATKAN EMPATI MAHASISWA PRODI BK UNIVERSITAS AHMAD DAHLAN
}

\author{
Tri Sutanti \\ Prodi Bimbingan dan Konseling Fakultas Keguruan dan Ilmu Pendidikan \\ Universitas Ahmad Dahlan \\ Email: Tantie_alaa@yahoo.co.id
}

\begin{abstract}
Student college of guidance and counseling programe as a counselors candidate is required to have concern for others, including empathy. This study aims to determine effectiveness modeling techniques to increase empathy in students majoring in guidance and counseling University of Ahmad Dahlan in Yogyakarta. The method used in this research is pre experiment with one group pretest-posttest with sampling through purposive sampling technique. The samples are 10 students majoring in guidance and counseling Ahmad Dahlan University Yogyakarta. Data collected by using a scale of empathy that has been proven valid and reliable and by using observation sheet communicative empathy. The results showed that modeling techniques can effectively increase empathy in students. This is evidenced by the results of Wilcoxon statistical test showed that the value of $\mathrm{Z}=-2810$ with $\mathrm{p}=0.005(<0.05)$, which means there is a significant difference given the level of empathy before treatment (pre-test) and after being given the treatment (post-test), The results could be used as consideration for educators in universities in order to develop empathy in students.
\end{abstract}

Keyword : empathy, modeling technique

\begin{abstract}
Abstrak: Mahasiswa bimbingan dan konseling sebagai calon konselor dituntut untuk memiliki kepedulian terhadap sesama termasuk berempati. Penelitian ini bertujuan untuk mengetahui efektiivitas teknik modeling untuk meningkatkan empati pada mahasiswa jurusan Bimbingan dan konseling universitas ahmad dahlan Yogyakarta. Metode yang digunakan dalam penelitian ini adalah penelitian pra eksperiment dengan one group pretest-posttest dengan pengambilan sampel melalui teknik purposive sampling. Sampel yang digunakan sebanyak 10 mahasiswa jurusan bimbingan dan konseling universitas ahmad dahlan Yogyakarta. Pengumpulan data dilakukan dengan menggunakan skala empati yang sudah teruji valid dan reliabel dan dengan menggunakan lembar observasi empati komunikatif. Hasil penelitian menunjukkan bahwa teknik modeling efektif dapat meningkatkan empati pada mahasiswa. Hal ini ditunjukan dengan hasil uji statistik wilcoxon menunjukkan bahwa nilai $\mathrm{Z}=-2.810$ dengan $\mathrm{p}=0,005(<0,05)$ yang berarti ada perbedaan yang signifikan tingkat empati sebelum diberikan perlakuan (pre-test) dan setelah diberikan perlakuan (post-test). Hasil penelitian ini dapat dijadikan sebagai bahan pertimbangan bagi para pendidik diperguruan tinggi dalam rangka mengembangkan empati pada mahasiswa.
\end{abstract}

Kata kunci:, empati, teknik modeling

\section{PENDAHULUAN}

Peningkatan mutu pendidikan merupakan masalah yang sangat esensial lebih-lebih berkenaan dengan upaya pengembangan dan peningkatan sumber daya manusia yang professional. Manusia yang professional adalah manusia yang menguasai ilmu pengetahuan dan 
teknologi serta manusia yang beriman dan bertaqwa. Banyak orang semakin sadar bahwa kunci utama kemajuan masayarakat ditentukan oleh pendidikan, sebab pendidikan adalah merupakan transformasi yang berfungsi membangun manusia yang berilmu pengetahuan, berteknologi dan bertaqwa. Oleh karena itu kemajuan tersebut dapat tercapai jika pendidikan harus berkualitas.

Kualitas guru merupakan salah satu kunci yang dapat menentukan dan dapat mempengaruhi kualitas pendidikan. Sebagai orang yang berpengaruh besar terhadap karakter siswa, guru bukan sekedar bertugas untuk transfer of knowledge tetapi hal lain yang menjadi tugas guru adalah untuk transfer of value kepada peserta didik. Maka dari itu guru merupakan komponen utama yang perlu dikembangkan melalui berbagai macam kegiatan dalam rangka menambah pengetahuan dan keterampilan untuk menjadi tenaga yang professional dan memiliki kepribadian yang unggul.

Guru bimbingan dan konseling sebagai orang yang patut untuk diteladani nampaknya masih banyak ditemukan sejumlah image negatif yang membawa citra dan nama baik guru BK di sekolah. Salah satunya adalah Guru BK sering dianggap sebagai polisi sekolah atau seksi keamanan sekolah. Menurut Sugiantoro (2011) menyatakan dalam surat kabar bahwa Fakta di lapangan, keberadaan Bimbingan dan Konseling (BK) di sekolah identik dengan masalah yang dihadapi siswa. Banyak siswa yang dianggap bermasalah diarahkan ke guru BK atau biasa disebut konselor untuk ditangani. Hal ini tidaklah salah, namun juga tak terlalu tepat. Ada kecenderungan guru BK ibarat polisi sekolah yang tugasnya menghukumi siswa bermasalah. Bahkan, siswa merasa tak nyaman berhubungan dengan guru BK, karena malu dan takut dianggap bermasalah oleh siswa-siswa lainnya. Koran Merapi, Selasa, 13 Desember 2011.

Hal senada telah disampaikan oleh Kartadinata (2009) bahwa masalah pokok yang dihadapi guru bimbingan dan konseling di sekolah masih banyak layanan bimbingan konseling lebih merupakan kebutuhan formal daripada kebutuhan actual, tidak dan tidak jarang bahwa bimbingan dan konseling lebih merupakan pekerjaan administrative yang lebih menekankan bukti fisik dari pada sebagai pekerjaan professional. Fenomena lain yang sangat meresahkan bahwa guru bimbingan kurang proaktif dan cara kerjanya lebih bersifat menunggu kedatangan konseli (Solo Pos, tanggal 11 Februari 2010) mereka kurang maksimal melakukan pemahaman terhadap siswa yang bermasalah. Mereka lebih banyak duduk di ruang bimbingan sambil menunggu siswa yang dikirim oleh guru atau wali kelas. Selama ini mereka belum berusaha secara maksimal untuk menemukan siswa yang perlu mendapatkan layanan bimbingan dan konseling. Fenomena ini menyiratkan makna bahwa empati guru bimbingan dan konseling nampaknya masih dipertanyakan.

Akhir-akhir ini kerap kali ditemukan sejumlah kabar yang berkaitan dengan kekerasan yang dilakukan oleh seorang guru kepada siswanya. Seperti yang terangkum dalam Solopos.com. Sukoarjo Senin, 17 November 2014. Salah satu siswa kelas IX SMP N 3 Nguter, Tri Aji Bayu Seto, 14 terpaksa dilarikan ke Rumah sakit Panti Waluyo Solo setelah keningnya penyok kena hantaman tempat sampah yang dilakukan guru setempat, BS (40). Kronologis kejadian bermula ketika upacara rutin sekolah akan dimulai. Saat itu, BS melihat adanya sejumlah siswa yang masih menggerombol dan asyik ngobrol di depan kelas.

Berdasarkan sejumlah kasus di atas menunjukkan bahwa sosok guru masih banyak ditemukan yang kurang memiliki pengertian, kelembutan, kasih sayang, dan empati. Betapa sulitnya sekarang menemukan orang yang selalu bertutur kata sopan, bersedia memahami kesulitan orang lain dan peduli terhadap penderitaan yang dialami oleh orang lain. Banyak para pejabat yang melakukan korupsi milyaran rupiah hingga tidak memperdulikan akan hak orang lain. Masyarakat modern yang semakin acuh tak acuh dengan sesama hingga niali-nilai kegotong royongan pada masayarakat indonesia semakin luntur. Semua fenomena tersebut menunjukkan bahwa rasa empati di masyarakat indonesia semakin menipis. Dengan demikian krisis empati menjadi satu hal yang harus diperhatikan dalam upaya pendidikan.

Guru Bimbingan dan Konseling selain dituntut memiliki kepribadian yang baik juga dituntut untuk dapat membantu dan mendukung mengembangkan karakter siswa yakni melalui layanan bimbingan konseling yang bersifat psikopedagogis. Pentingnya peranan konselor sekolah dalam pendidikan karakter, dinyatakan 
oleh American School Conselor Associattion (2011) yakni :

Profesioanl school counselor need to take an active role in initiating, facilitating and promoting character education program in the school curiculum. The Profesioanl school counselor, as a part of the school community and as highly resourceful person, takes an active role by working cooperatively with the teacher and administration in providing charakter education in the school as an integral part of the school curiculum and activities ASCA (1998)

Dengan demikian konselor bekerja bersama-sama dengan para guru, dan administrator sekolah memiliki peranan penting untuk menumbuhkan karakter pada anak didik. Sebagai pendidik karakter siswa, maka konselor sekolah perlu memahami bagaimana menjadi konselor yang berkarakter, memiliki kepribadian yang dapat menjadi suri tauladan bagi siswanya, peka dan cepat tanggap terhadap masalah yang dialami siswa dan mampu memberikan pelayanan bimbingan konseling yang efektif untuk membantu mengoptimalkan perkembanagan peserta didik yang berkarakter. Semua ini dapat diawali dengan rasa empati yang melekat dalam diri guru Bimbingan Konseling/Konselor.

Borba (2008) menyebutkan tujuh kebajikan utama yang akan menjaga sikap baik seumur hidup pada anak, yakni empati, hati nurani, kontrol diri, rasa hormat, kebaikan hati, toleransi dan keadilan. Pernyataan Borba tersebut menunjukkan bahwa empati memiliki kedudukan yang sangat esensi untuk menjaga sikap baik pada diri anak. Empati merupakan suatu aktivitas untuk memahami apa yang sedang dipikirkan dan dirasakan orang lain, tanpa yang bersangkutan kehilangan kontrol dirinya.

Dengan demikian dapat diartikan bahwa empati menjadi hal yang sangat berperan dalam menjalin hubungan sosial dalam kehidupan bermasyarakat. Ditegaskan oleh Rogers (dalam Jones 2012), bahwa empati adalah salah satu unsure kunci dalam menciptakan hubungan interpersonal termasuk dalam proses terapeutik. Maka empati dapat dijadikan sebagai salah satu bagian dari sebuah karakter yang harus ditanamkan pada diri seseorang. Penanaman karakter tersebut tidak hanya menjadi tanggung jawab dari orang tua, tetapi juga merupakan tanggung jawab dari berbagai pihak masyarakat, termasuk pendidik di berbagai jenjang pendidikan.

Menjadi guru yang profesioanl dan penuh empati serta dapat menjadi model yang baik bagi peserta didiknya tidak secara tiba-tiba dapat dibentuk setelah menjadi guru di sekolah. Pengembangan empati haruslah mulai ditanamkan sejak dini oleh para calon pendidik termasuk calon guru BK semenjak ia masih di bangku perkuliahan. Di sinilah peran Lembaga Pendidikan Tenaga Kependidikan (LPTK) sangat diperlukan. LPTK diharapkan dapat menjadi pencetak calon-calon pendidik yang profesional dan memiliki pribadi yang unggul. Selain membekali segi teori dan praktik dibidang keahlian (keilmuan dan keguruan), LPTK juga harus mampu menyiapkan calon pendidik yang memiliki kopetensi kepribadian yang baik. Salah satu kompetensi kepribadian yang harus dimiliki adalah kepemilikan rasa empati terhadap sesama.

Mahasiswa merupakan aset cadangan, harapan bangsa untuk masa depan. Menjadi mahasiswa itu merupakan kebanggaan dan juga sebagai tanggung jawab besar sebagai agen pembawa perubahan. Mahasiswa adalah seseorang yang akan memberikan solusi terhadap permasalahan yang dihadapi masyarakat. Sebagai kaum intelektual, mahasiswa memiliki peranan yang sangat penting dalam kehidupan berbangsa. Sebagai Agent Of Change, maka mahasiswa tidak hanya dituntut mampu untuk bersifak kritis, namun juga harus memiliki pribadi yang baik.

Namun, harapan tersebut nampaknya masih membutuhkan berbagai upaya dari berbagai pihak untuk dapat mewujudkannya. Hal itu dibuktikan dari berbagai kasus yang dilakukan oleh sejumlah mahasiswa di Indonesia. Seperti yang terangkum News detik.com Jumat 28 November 2014. Ratusan mahasiswa turun ke jalan. Mereka memblokir jalan di pertigaan UIN Sunan Kalijaga, Jl Laksda Adisutjipto, Yogyakarta. Bentrok dengan polisi tak terhindarkan Bentrokan diawali saat polisi mulai membuka jalan yang diblokir mahasiswa agar pengguna jalan bisa melintas pada pukul 16.00 WIB. Ternyata mahasiswa 'mengganggu' pengguna jalan dengan melemparkan batu sebagai aksi demostrasi akan naiknya harga BBM.

Berdasarkan kasus-kasus di atas menunjukkan bahwa masih banyak dibutuhkan berbagai upaya dari lembaga pendidikan (LPTK) 
untuk dapat menghasilkan tenaga pendidik yang tidak hanya unggul dalam keilmuwan, tetapi juga unggul dalam kecerdasan emosional salah satunya adalah empati. Empati merupakan kemampuan individu untuk memahami dan ikut merasakan kondisi yang dialami oleh orang lain baik yang dikenalnya ataupun tidak, tanpa yang bersangkutan terhanyut di dalam perasaan itu. Melalui empati, hubungan interpersonal akan semakin harmonis yang dilandasi saling pengertian, saling menghargai, dan saling menghormati. Oleh karenanya, krisis empati yang melanda generasi Indonesia pada saat ini adalah masalah penting yang harus diperhatikan dan dicari solusinya baik dalam konteks bermasyarakat maupun dalam upaya pendidikan.

Dari hasil observasi yang peneliti lakukan pada saat proses perkuliahan pada mata kuliah teori dan teknik konseling dan pemahaman tingkah laku, menunjukkan bahwa rasa kepedulian yang dimiliki oleh mahasiswa BK UAD angkatan 2011 masih rendah. Hal itu ditunjukkan dari pengerjaan tugas kuliah dan pembuatan kelompok belajar. Sejumlah mahasiswa masih kerap ditemukan memilih teman kelompok yang sama-sama pintar dan yang mengalami kesulitan dalam belajar menjadi kurang mendapat kesempatan untuk belajar bersama teman yang lebih bisa. Selain itu, informasi tersebut juga diperkuat oleh pernyataan sejumlah mahasiswa SE (Student Employment) yang bekerja di laboratorium BK UAD. Menurut infomrasi dari sejumlah mahasiswa SE, bahwa mahasiswa BK angkatan 2011 banyak yang susah untuk bersabar ketika menunggu pelayanan di laboratorium dan sukar untuk diarahkan. Hasil Observasi dan wawancara terhadap mahasiswa SE, Kamis, 20 November 2014

Modeling merupakan salah satu teknik dalam membantu individu untuk mempelajari perilaku tertentu. Modeling ialah belajar melalui observasi dengan menambahkan atau mengurangi tingkah laku yang teramati, menggeneralisir berbagai pengamatan sekaligus, melibatkan proses kognitif. Dalam kehidupan sehari-hari banyak perilaku individu terbentuk sebagai hasil dari peniruan dari model/contoh. Hasil penelitian R.S. \& Thomas, M;H. (2006). menemukan bahwa orang-orang termasuk anak yang telah memandang model (orang lain) yang murah hati akan menjadi orang yang murah hati dibandingkan dengan orang-orang yang tidak memandang model prososial. Akan tetapi menurut penuturan dosen BK UAD bagian kemahasiswaan, menyatakan bahwa teknik modeling ini belum pernah diaplikasikan pada mahasiswa BK untuk mengembangkan empati dalam suasana layanan Bimbingan dan Konseling. Hasil wawancara dengan Dosen kemahasiswaan UAD, Kamis, 20 November 2014

Empati merupakan dasar dari kecerdasan moral. Kebajikan moral yang pertama ini mengasah kepekaan individu terhadap perbedaan sudut pandang dan pendapat orang lain. Empati berperan meningkatkan sifat kemanusiaan, keadaban dan moralitas. Empati merupakan emosi yang mengusik hati nurani siswa ketika melihat kesusahan orang lain. Hal tersebut juga membuat siswa menunjukkan toleransi dan kasih sayang, memahami kebutuhan orang lain, serta mau membantu orang lain yang sedang dalam kesulitan. Siswa yang belajar empati akan jauh lebih pengertian dan penuh kepedulian serta lebih mampu mengendalikan kemarahan.

Rogers dalam (Paderson , 2008) menyatakan " empathy as the ability to perceive the internal frame of reference of another with accuracy and with the emotional component and meaning with pertain thereto as if one were the person without ever losing the as if condition" Empati adalah kemampuan untuk memahami kondisi atau keadaan pikiran orang lain dengan tepat, dan tanpa kehilangan kondisi nyata. Seorang yang empati digambarkan sebagai seorang yang toleran, mampu mengendalikan diri, ramah, mempunyai pengaruh serta bersifat humanistic. Empati adalah merasakan sesuatu bentuk atau perasaan tertentu seperti apa yang dirasakan atau dideritakan oleh orang lain. beda halnya dengan simpati yang menimbulkan ketertarikan semata tetapi tidak adanya sesuatu tindakan ataupun ketertarikan secara emosional. Kemampuan mengindera perasaan seseorang sebelum yang bersangkutan mengatakannya merupakan intisari empati. Tanpa kemampuan ini orang dapat menjadi terasing, salah menfasirkan perasaan yang berakibat rusaknya hubungan. Salah satu wujud empati adalah ketika seseorang cenderung menyamaratakan orang lain dengan dirinya.

Selanjutnya menurut Goleman (2007) Empati merupakan bagian penting kemampuan sosial. Empati juga merupakan salah satu unsurunsur dari kecerdasan sosial. Ia terinci dan berhubungan erat dengan komponen-komponen 
yang lain, seperti empati dasar, penyelarasan, ketepatan empatik dan pengertian sosial. Empati dasar yakni meliliki perasaan dengan orang lain atau merasakan isyarat-isyarat emosi non verbal. Penyelarasan yakni mendengarkan dengan penuh resepivitas, menyelaraskan diri pada seseorang. Ketepatan empatik yakni memahami pikiran, perasaan dan maksud orang lain dengan pengertian sosial yakni mengetahui bagaimana dunia sosial bekerja.

Dari berbagai definisi di atas dapat disimpulkan bahwa empati merupakan suatu kemampuan untuk memahami apa yang sedang dipikirkan dan dirasakan orang lain, yang dapat dikomunikasikan secara verbal maupun non verbal tanpa yang bersangkutan kehilangan kontrol dirinya, sehingga seseorang tersebut tidak hanyut dalam suasana orang lain. Siswa yang memiliki empati dapat bergaul dan bersosialisasi dengan orang lain dengan baik, dapat menyesuaikan diri dengan lingkungan di sekitarnya dan dapat diterima oleh lingkungan dimanapun individu itu berada.

Empati memiliki sejumlah komponen. Menurut Taufik (2012) Komponen empati terdiri dari komponen kognitif, komponen afektif dan komponen komunikatif. Sedangkan Menurut Davis (1983) secara global ada dua komponen dalam empati, yaitu komponen afektif yang masing-masing mempunyai dua spek, yaitu perspektif taking dan fantacy, sedangkan komponen afektif meliputi Emphatic Concern dan Personal Distress.

Menurut Decety (2012) perkembangan empati didasari oleh kesadaran reflektif dari emosi diri sendiri dan emosi orang lain, dan niat merupakan karakteristik kunci dari pengalaman empati. Aspek intuitif empati yang tersedia untuk bayi berevolusi dan berkembang, bentuk lanjutan dari empati didahului oleh kemampuan untuk mengirim dan merespon sinyal emosional.

Sejumlah penelitian yang dilakukan oleh Nanci Eisenberg (dalam Taufik 2012) diawali dari pertanyaan bagaimana cara mengajarkan empati pada individu atau anak. Dari sejumlah penelitian yang ia lakukan, selanjutnya ia merumuskan bahwa ada beberapa cara untuk mengajarkan empati, yaitu induksi, nasihat moral, dan modeling.

Kemampuan empati menjadi hal yang sangat pokok yang harus dimiliki pada diri manusia, baik anak-anak-, remaja maupun dewasa. Empati harus sering diasah sejak dini.
Bahkan, meskipun usia seseorang telah beranjak dewasa, harus tetap melatih empati. Untuk mewujudkan generasi masyarakat yang penuh dengan empati maka mengembangkan empati menjadi tanggung jawab bagi orang tua, pendidik dan masyarakat. Salah satu teknik yang dapat dipakai untuk mengembangkan empati pada individu adalah teknik modeling. Dalam lingkup pendidikan tinggi, empati juga menjadi hal yang penting untuk ditanamkan, terlebih bagi mahasiswa sebagai calon guru/konselor.

Modeling adalah belajar dengan mengamati, menirukan, dengan menambahkan atau mengurangi tingkah laku yang teramati. Modeling dilakukan oleh perilaku seseorang individu atau kelompok (model) sebagai stimulus terjadinya pikiran, sikap, dan perilaku yang serupa di pihak pengamat. Jones, (2011) modeling merupakan teknik untuk mengajari si pengamat keterampilan dan aturan perilaku. Modeling juga dapat menghambat dan menghilangkan atau mengurangi hambatan perilaku yang sudah ada dalam repertoar Dalam modeling, perilaku orang yang dijadikan model dapat berfungsi sebagai pengingat atau isyarat bagi orang yang mengamatinya. .

Menurut Corey (2005) Istilah pemodelan dapat diartikan sebagai belajar dengan mengamati, menirukan, belajar sosialisasi dan belajar dengan menggantikan (vicarious learning) telah digunakan dengan pengertian yang sama dan secara bergantian. Semuanya berarti proses berbuat yang dilakukan oleh perilaku seseorang individu atau kelompok (model) sebagai stimulus terjadinya pikiran, sikap, dan perilaku yang serupa di pihak pengamat. Melalui belajar dengan mengamati, klien sendiri bisa belajar untuk menunjukkan perbuatan yang dikehendaki tanpa harus belajar lewat trial and eror. Bandura 1986 (Dalam Corey 2005) menegaskan peranan pemodelan dalam pengembangan dan modifikasi banyak dari perilaku manusia.

Terdapat beberapa tipe model dalam modeling. Model yang dapat digunakan untuk belajar tingkah laku adalah live model yang terdiri dari mastery model dan coping model, symbolik model, dan multiple model.

Corey (2005) beberapa tipe model yang dapat digunakan dalam situasi terapeutik. Seorang model hidup bisa mengajar klien perilaku yang tepat, mempengaruhi sikap dan nilai, mengajar keterampilan sosial. misalnya 
terapis bisa memberi model dari suatu ciri yang benar-benar diharapakan akan dimiliki oleh klien.

Terapis perilaku bisa juga menggunakan model simbolik. Perilaku model ditunjukkan dalam film, pita video, dan alat perekam yang lain. Bandura 1969 (dalam Corey 2005) menulis bahwa model simbolik telah berhasil digunakan dalam berbagai situasi.

Selanjutnya model ganda (mulitple model) terutama relevan untuk terapi kelompok. $\mathrm{Si}$ pengamat bisa mengubah sikap dan belajar dari keterampilan baru melalui pengamatan terhadap rekan yang berhasil (atau lewat pengamatan sesama pimpinan). Keuntungan dari model ganda adalah bahwa dari beberapa alternatif yang ada, pengamat belajar cara berperilaku, oleh karena mereka melihat beraneka ragam gaya perilaku yang tepat dan berhasil.

Dalam rangka mengembangkan empati pada mahasiswa prodi $\mathrm{BK}$ UAD, model yang dapat diberikan yakni live model, dengan menyajikan model sebaya yang memiliki perlaku dan pengelaman empati, syombolik model dengan memutarkan film dan cerita para tokoh yang sukses berkat sikap kepedulian yang dimiliki serta memalui dinamika kelompok dalam layanan bimbingan kelompok, anggota kelompok dapat belajar empati dari pemimpin kelompok atau dengan anggota kelompok yang lain.

Berdasarkan adanya berbagai fenomena tersebut maka peneliti mempunyai suatu keinginan untuk meningkatkan empati mahasiswa program studi BK UAD Yogyakarta angakatan 2011 melalui teknik modeling. Melalui empati, yakni memahami situasi dan kondisi orang lain, maka calon konselorr dapat mengembangkan hubungan sosial dalam kehidupan bermasyarakat dan dapat mengembangkan hubungan interpersonal dalam proses pelayanan konseling.

Tujuan penelitian ini adalah: Untuk mengetahui tingkat keefektifan teknik modeling untuk meningkatkan empati pada mahasiswa, yang akan diucicobakan pada mahasiswa program studi Bimbingan dan Konseling UAD Yogyakarta Angakatan Tahun 2011.

\section{METODE PENELITIAN}

Rancangan penelitian yang digunakan peneliti dalam penelitian ini adalah Pra Experimental Design menggunakan One Group Pretest-Posttest atau disebut juga dengan One Group Experiment (rancangan penelitian yang menggunakan satu kelompok subyek). Pertamatama dilakukan pengukuran, kemudian dikenakan perlakuan untuk 7 kali perlakuan, selanjutnya dilakukan pengukuran untuk kedua kalinya. Populasi dalam penelitian ini adalah mahasiswa prodi BK UAD Yogyakarta angkatan tahun 2014, sedangkan Sampel penelitian dalam peenelitian ini menggunakan teknik purposive sampling.

Dalam penelitian ini instrumen yang digunakan oleh peneliti adalah skala empati sebagai metode pokok untuk mengumpulkan data tentang empati dengan nilai reliebel alpha cronbach sebsar 0 ,955. Empati yang diukur meliputi kemampuan perspektif taking, fantacy, emotional concern dan personal distress. Selain itu peneliti menggunakan lembar observasi empati komunikatif dalam pelaksanaan implementasi teknik modeling. Empati komunikatif yang diobservasi meliputi raut wajah, nada suara, perhatian, tatapan mata, dan kata-kata verbal.

Untuk membuktikan hipotesis penelitian berupa pengujian efektivitas teknik modeling ini digunakan uji Wilcoxon dua sisi. Analisis data secara keseluruhan dilakukan menggunakan bantuan perangkat lunak SPSS 19.

\section{HASIL DAN PEMBAHASAN}

\section{Hasil}

Berdasarkan gambaran dari pre-test dan posttest atau sebelum dan sesudah diberikan perlakuan dengan teknik modeling, keadaan empati mahasiswa mengalami kenaikan signifikan. Untuk melihat peningkatan tingkat empati mahasiswa dapat dilihat pada tabel berikut: 
Tabel: 1 Perbedaan Hasil Skor Pretes dan Posttest Efektifitas Teknik Modeling untuk Meningkatkan Empati Mahasiswa BK UAD

\begin{tabular}{|c|c|c|c|c|c|}
\hline No & $\begin{array}{c}\text { Nama } \\
\text { (Inisial) }\end{array}$ & $\begin{array}{c}\text { Pree } \\
\text { test }\end{array}$ & Kategori & Post test & Kategori \\
\hline 1 & LN & 161 & Tinggi & 169 & Tinggi \\
\hline 2 & AST & 147 & Sedang & 159 & Tinggi \\
\hline 3 & WN & 124 & Sedang & 133 & Sedang \\
\hline 4 & ULF & 126 & Sedang & 137 & Sedang \\
\hline 5 & VNI & 127 & Sedang & 134 & Sedang \\
\hline 6 & QDS & 112 & Kurang & 122 & Sedang \\
\hline 7 & ANG & 160 & Tinggi & 167 & Tinggi \\
\hline 8 & JL & 118 & Kuramg & 127 & Sedang \\
\hline 9 & MY & 120 & Kurang & 131 & Sedang \\
\hline 10 & EBH & 116 & Kurang & 124 & Sedang \\
\hline
\end{tabular}

Dari tabel diatas terlihat bahwa empati mahasiswa pada kelompok perlakuan mengalami kenaikan setelah para mahasiswa diberikan teknik modeling dalam kegiatan bimbingan kelompok. Dari hasil pretest terdapat, $40 \%$ mahasiswa yang memiliki empati pada kategori kurang, $40 \%$ mahasiswa yang memiliki empati pada kategori sedang, dan $10 \%$ mahasiswa memiliki empati pada kategori tinggi. Namun setelah diberikan layanan bimbingan kelompok dengn teknik modeling, hasil post test menunjukkan terjadi perubahan empati pada mahasiswa. Yakni, terdapat $0 \%$ mahasiswa yang memiliki empati pada kategori kurang, $70 \%$ mahasiswa yang memiliki empati pada kategori sedang, dan $30 \%$ mahasiswa memiliki empati pada kategori tinggi.

Berdasarkan hasil rata-rata skor pretest dan post test, diperoleh hasil sebagai berikut:

Tabel : 2 Perbedaan Rata-rata Hasil Pretest dan Posttest

\begin{tabular}{|ll|r|c|}
\hline & Hasil & N & Mean \\
\hline Empati & Pre Test & 10 & 131,1 \\
& Post Test & 10 & 140,3 \\
\hline
\end{tabular}

Berdasarkan tabel di atas menunjukkan terjadi peningkatan rata-rata skor dari sebelum diberikan teknik modeling (pre test) dengan setelah diberikan teknik modeling (post test)

Untuk mendapatkan gambaran lebih jelas, berikut dipaparkan dalam bentuk diagram batamg grafik Rata-rata Hasil Pretest dan Posttest Empati mahasiswa yang diberikan teknik modeling

Grafik :1
Rata-rata Hasil Pretest dan Posttest Empati Mahasiswa

\section{Rata-rata Hasil Pretest dan Posttest}

$\square$ pre test $\square$ post test

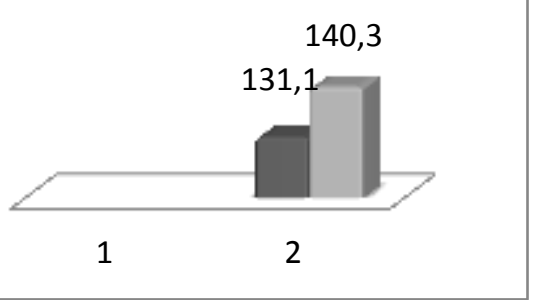

Berdasarkan hasil analisis data skor setiap aspek empati pada 10 mahasiswa kelompok eksperimen yang mendapat teknik modeling untuk meningkatkan empati pada mahasiswa diperoleh hasil sebagaimana tertera pada tabel berikut ini :

Tabel : 3. Hasil Rerata Pretest dan Posttest Pada

\begin{tabular}{|l|l|l|l|l|}
\hline No & \multicolumn{1}{|c|}{ Tiap Aspek } \\
Aspek & $\begin{array}{l}\text { Rata- } \\
\text { rata } \\
\text { pre } \\
\text { test }\end{array}$ & $\begin{array}{l}\text { Rata- } \\
\text { rata } \\
\text { Post } \\
\text { test }\end{array}$ & $\begin{array}{l}\text { Gain } \\
\text { rata- } \\
\text { rata }\end{array}$ \\
\hline 1 & $\begin{array}{l}\text { Perspektif } \\
\text { taking }\end{array}$ & 35,5 & 37,8 & 2,3 \\
\hline 2 & Fantacy & 28,8 & 31,3 & 2,5 \\
\hline 3 & $\begin{array}{l}\text { Emotional } \\
\text { concern }\end{array}$ & 35,1 & 37,5 & 2,4 \\
\hline
\end{tabular}




\begin{tabular}{|l|l|l|l|l|}
\hline 4 & $\begin{array}{l}\text { Personal } \\
\text { distress }\end{array}$ & 31,7 & 33,7 & 2 \\
\hline
\end{tabular}

Berdasarkan data di atas menunjukkan bahwa setiap aspek empati mengalami kenaikan. Dari sebelum diberikan teknik modeling dan sesudah diberikan teknik modeling. Aspek yang mengalami kenaikan paling tinggi yakni pada aspek fantacy, selanjutnya pada aspek emotional concern, disusul oleh aspek perspektif taking dan terakhir adalah pada aspek personal distress.

Untuk mendapatkan gambaran lebih jelas, berikut dipaparkan dalam bentuk diagram batamg grafik Rata-rata Hasil Pretest dan Posttest Empati mahasiswa BK pada tiap aspek empati.

Grafik : 2

Hasil Rerata Pretest dan Posttest Pada Tiap Aspek

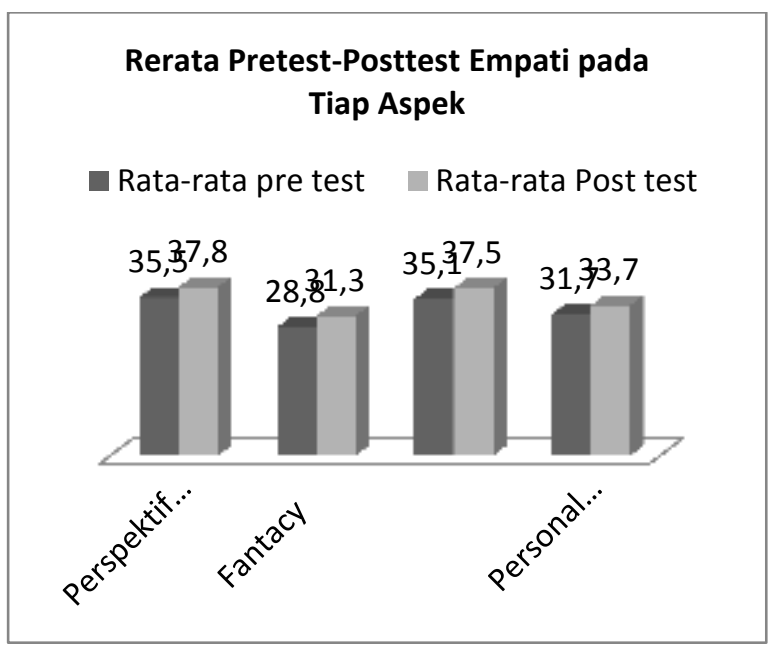

Pengujian efektifitas Teknik Modeling untuk meningkatkan empati pada mahasiswa BK UAD Angkatan tahun 2011 adalah dengan menggunakan rumus wilcoxon karena jumlah subyeknya kurang dari 30. Pengujian hipotesis dengan membandingkan hasil rata-rata dari Pretest dan Post-test. Berikut merupakan hasil dari perbandingan tersebut :
Tabel : 4 Hasil Perbandingan Antara data pre test dan post test

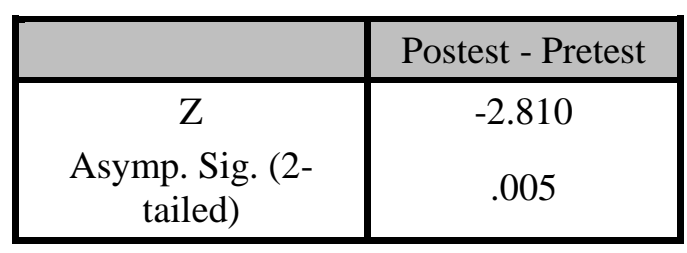

Berdasarkan tabel tersebut dapat dipaparkan bahwa dengan nilai $\mathrm{Z}=-2.810$ memiliki peluang 0,005 . Nilai ini kemudian dibandingkan dengan $\mathrm{w}$ tabel, jika hasil yang diperoleh w hitung < w tabel maka hipotesis Ho ditolak. Pada penghitungan tersebut $\mathrm{w}$ hitung adalah 0,005 dan $\mathrm{w}$ tabel adalah 0,05 sehingga $0,005<0,05$ yang berarti mendekati nilai 0 sehingga signifikan. Oleh karena itu dapat disimpulkan bahwa hipotesis Ho ditolak.

Penolakan Ho berarti ada perbedaan antara rata-rata empati mahasiswa dari hasil Pretest dan Postest, sehingga teknik modeling dapat dikatakan efektif untuk meningkatkan empati pada mahasiswa.

Sedangkan untuk hasil observasi Secara keseluruhan pertemuan ketujuh dalam proses bimbingan kelompok ini dapat dikatakan berjalan dengan lancar dan optimal. Progres perilaku empati mahasiswa makin meningkat dan semua mahasiswa terlihat sangat antusias dan senang mengikuti kegitan layanan bimbingan kelompok yang diadakan

Jika dilihat perbedaan empati komunikatif dari pertemuan pertama, pertemuan yang terakhir ini anggota kelompok mampu menunjukkan empati komunikatif yang sangat baik.

Secara lebih rinci perbedaan hasil observasi empati pada aspek komunikatif pada pertemuan pertama dengan pertemuan kesembilan adalah sebagai berikut:

Tabel: 5 Perbedaan Hasil Observasi Aspek Empati Komunikatif Pada Pertemuan Pertama Dengan Pertemuan Ketujuh

\begin{tabular}{|l|l|l|l|l|l|}
\hline No & Kategori & \multicolumn{2}{l|}{ Pertemuan Pertama } & \multicolumn{2}{l|}{ Pertemuan Ketujuh } \\
\cline { 3 - 6 } & & $\begin{array}{l}\text { Frekuens } \\
\text { i }\end{array}$ & Prosentase & Frekuensi & Prosentase \\
\hline 1 & Tinggi & 0 & $0 \%$ & 3 & $30 \%$ \\
\hline 2 & Sedang & 4 & $40 \%$ & 7 & $70 \%$ \\
\hline 3 & Kurang & 5 & $50 \%$ & 0 & $0 \%$ \\
\hline
\end{tabular}




\begin{tabular}{|l|l|l|l|l|l|}
\hline 4 & Rendah & 1 & $10 \%$ & 0 & $0 \%$ \\
\hline
\end{tabular}

Tabel diatas menunjukkan adanya perbedaan hasil observasi pada empati aspek komunikatif dari anggota kelmpok. Pada pertemuan pertama bimbingan kelompok teknik modeling terdapat $40 \%$ anggota kelompok yang memiliki aspek empati komunikatif pada kategori sedang, $50 \%$ pada kategori kurang dan $10 \%$ pada kategori rendah. Sedangkan pada pertemuan ketujuh aspek empati komunikatif dari anggota kelompok sebanyak $30 \%$ berada pada kategori tinggi dan $70 \%$ berada pada kategori sedang.

\section{Pembahasan}

Berdasarkan hasil uji efektivitas teknik modeling yang diberikan kepada mahasiswa selama 7 kali pertemuan dengan pra experimental design, memperoleh hasil data yang menunjukkan terjadi perbedaan antara rata-rata empati mahasiswa dari hasil Pretest dan Postest, sehingga teknik modeling dapat dikatakan efektif untuk meningkatkan empati pada mahasiswa. Hasil penelitian ini senada dengan penelitian yang dilakukan oleh R.S. \& Thomas, M;H. (2006).

Menurut R.S. \& Thomas, M;H. (2006) dalam jurnal yang berjudul "children's imitation of agressive and prosocial behavior when vieweng alone and in pairs. Journal of Communication, 27, 199-205. Menemukan bahwa orang-orang termasuk anak yang telah memandang model (orang lain) yang murah hati akan menjadi orang yang murah hati dibandingkan dengan orang-orang yang tidak memandang model prososial. Sejalan dengan menggunakan simbolik model, live model dan multiple model, dan konselor sendiri memberikan contoh bagaimana selalu bersikap empati kepada anggota kelompok, dan melalui simbolik model dengan memutarkan film tanah air surga dan sang pencerah dapat memberikan contoh bagi anggota kelompok untuk berempati. Selain itu model yang datang dari kakak tingkat dan sesama anggota kelompok dapat mendorong mereka untuk tergerak berperilaku empati.

Teknik modeling yang teruji efektivitasnya untuk meningkatkan empati mahasiswa prodi BK ini selain menggunakan simbolik model, juga menggunakan live model yang mengutamakan model sebaya. Model sebaya ini, dengan mendatangkan kakak tingkat dari mahasiswa yang menjadi sample penelitian. Kakak tingkat yang dipilih adalah mereka yang memiliki empati yang tinggi dan punya pengalaman dalam kegiatan sosial.

Pertimbangan model sebaya ini dipilih berdasarkan pada pandangan dari Gantina (2011) yang menyatakan terdapat sejumlah hal yang harus diperhatikan dalam penerapan modeling, diantaranya bahwa Anak lebih senang meniru model seusianya daripada model dewasa. Senada dengan hasil peneltian yang dilakukan oleh Bandura 1969 (dalam Corey 2005) menunjukkan bahwa seorang model yang serupa dengan si pengamat dalam usia, jenis kelamin, kelompok etnik, dan sikap kemungkinannya lebih besar untuk ditiru daripada seorang model yang tidak ada kesamaan dengan pengamat.

\section{SIMPULAN DAN SARAN}

1. Berdasarkan hasil analisis data diketahui bahwa teknik modeling yang dieksperimentkan pada 10 mahasiswa BK UAD terbukti efektif dapat meningkatkan empati mahasiswa. Empati yang dimiliki mahaiswa sebelum diberi teknik modeling diperoleh mean pre test sebesar 131,1 sedangkan empati mahasiswa setelah diberi teknik modeling diperoleh mean posttest sebesar 140,3.

2. Peningkatan empati mahasiswa juga dapat dilihat berdasarkan hasil observasi empati komunikatif pada saat proses kegiatan bimbngan kelompok dengan teknik modeling pada setiap pertemuan. Pada pertemuan pertama kondisi empati mahasiswa berada pada kategori tinggi $0 \%$, kategori sedang 40 $\%$, kategori kurang $50 \%$ dan kategori rendah $10 \%$. Sedangkan pada pertemuan terakhir hasil observasi empati komunikatif mahasiswa berada pada kategori tinggi $30 \%$, kategori sedang $70 \%$, kategori kurang $0 \%$ dan kategori rendah $0 \%$.

Temuan penelitian menunjukkan bahwa teknik modeling efektif untuk meningkatkan empati mahasiswa. Hasil penelitian ini dapat dijadikan sebagai bahan rujukan bagi para Dosen atau Konselor dalam upaya mengembangkan empati mahasiswa. Selain itu, penelitian ini 
memberikan informasi bagi LPTK tentang manfaat teknik modeling yang dikemas dalam pelayanan bimbingan kelompok di perguruan tinggi. Diharapkan LPTK memiliki unit khusus sebagai wadah untuk pelayanan bimbingan dan konseling guna mengembangkan aspek non akdemik mahasiswa seperti sikap empati.

\section{DAFTAR RUJUKAN}

Arikunto, Suharsimi. 2006. Prosedur Penelitian Suatu Pendekatan Praktek. Jakarta : Rineka Cipta.

ASCA. 2011 The Profesional Counselor and Character Education. 2011 https://www.schoolcounselor.org/asca/media/asc a/home/position\%20statements/PS_CharacterEd ucation. Diunduh pada Jumat 17 Mei 2012 Pukul 10.55

Bandura, A. 1997. Self Efficacy, the exercise of control. New York: WH. Freeman Company

Baron-Cohen, S. Wheelwright, S. (2004). The Empathy Quotient: An Investigation of Adults With Asperger Syndrome or High Fungtioning Autism, and Normal Sex Differences. Journal of Autism and Developmental Disorder, 34, 2, 163-175

Borba, Michele (2008), Membangun Kecerdasan Moral, Gramedia Pustaka Utama, Jakarta

Corey, Gerald. 2005. Theory and Practice of Counseling \& Psichoterapy. Seventh edition. USA: Broks/Cole Thompson

Jean Decety \& margarita svetlova.2012. Putting together phylogenetic and ontogenetic perspectives on empathy. Journal Developmental Cognitive Neuroscience. Http://www.elsever.com/locate dcn

David. (2004). "Measuring Emphaty: Reability and Validation Of the Empaty Question". Cambridge University press, 911-924.

Davis, E.M. (1983). The Effect Of Disposisional Empathy on Emotional Reaction and Helping: A Multidimensional Approach. Journal Of personality, 51, 167-187

Drabman, R.S. \& Thomas, M;H. (2006). children's imitation of agressive and prosocial behavior when vieweng alone and in pairs. Journal of Communication, 27, 199-205.
Goleman, Daniel. 1999. Kiat-Kiat Membesarkan Anak yang Memiliki Kecerdasan Emosional. Jakarta: Pustaka Utama. 2002. Kecerdasan Emosional Mengapa EI lebih penting daripada IQ. Jakarta: Pustaka Utama. 2007.Social Intelligence: Ilmu Baru tentang Hubungan Antar Manusia, PT Gramedia Pustaka Utama: Jakarta

Hergenhans, B.R. \& Olson. 2010. Theories of learning. Jakarta: Kencana Perdana Media Group

Http:// www. solopos. Com /2014 /11/ 17/

kekerasan-terhadap-siswa-guru-smpn-di-

sukoharjo-lempar-tempat-sampah-ke-murid-

552835. Diakses Jumat tanggal 28 November 2014 pukul 22.20.

Jones, Nelson. 2011. Teori dan Praktik Konseling dan Terapi. Yogyakarta: Pustaka Pelajar.

Jonson, J. Bar. Ann, Haggin D, Alesandro.(2007). Adolecent Empathy and Prosocial Behavior in the Multidemensional Contex Of School Culture. Journal of Genetic Psichology, 168 (3), 231-250

Komalasari, Gantina dkk. 2011. Teori dan Teknik Konseling. Jakarta: Indeks

Kraus, M., Stephane C., \& Keltner, D. 2010. Social Class, Contextualism, and Empathic Accuracy. Psychological Science, 21, 1716-1723

Paderson, Paul.B. 2008. Inclusive cultural empathy. First Edition. Washington: American Psichological Assosiation

Pickett,,C.L. Gardner, W.L, \& Knowles,M. (2004). Getting a cue: The need to belong and enhanced sensitivity to social Cues. Personality and social Psichology Buletin, 30, 1095-1107.

Rahman, Fathur.(2011). Kualitas Empati dan Intensi Prososial Sebagai Dasar Kepribadian Konselor. http://staff.uny.ac.id. Diunduh pada Kamis 17 Mei 2012 Pukul 22.25

Santrock JW. 2010. Life Span Development. Dallas: University of texas

Sugiyono, 2010. Metode Penelitian Pendidikan(pendekatan Kuantitatif, kualitatif, dan $R \& D$ ).Bandung : alfabeta

Suwarjo.2009. Modul Praktik Keterampilan Konseling. Yogyakarta: UNY Press 
Taufik.2012. Empati Pendekatan Psikologi Sosial. Jakarta: Raja Grafindo Persada. 